\title{
Early development and allometric growth patterns of rheophilic cyprinid common dace Leuciscus leuciscus (Cyprinidae: Leuciscinae)
}

\author{
Krzysztof Kupren $^{1} \cdot$ Izabela Rams $^{2} \cdot$ Daniel Żarski $^{2,3} \cdot$ Dariusz Kucharczyk ${ }^{2}$
}

Received: 18 June 2015/Revised: 2 September 2015/Accepted: 5 January 2016/Published online: 5 February 2016

(C) The Author(s) 2016. This article is published with open access at Springerlink.com

\begin{abstract}
The present work is the first comprehensive description of easily recognizable morphological changes, allometric growth, and behaviour during early ontogeny of endangered common dace Leuciscus leuciscus, establishing a reference for its normal development under laboratory conditions. Based on the external morphology, three different periods and eight characteristic steps (ES9-JS1; ES-embryonic steps, JS-juvenile steps) were identified between hatching and 30 days post-hatch at $25^{\circ} \mathrm{C}$. This study shows that all allometric changes occurred after notochord flexion across a wide range of body lengths (15.35-21.78 mm TL) reflecting the larvae-juvenile transition. Observations on the early development of common dace confirmed the relatively uniform development of cyprinid species and support the hypothesis of differential growth patterns for primary functions during early ontogeny. Differences in relative growth between common dace and other species might be attributed to their different size at hatching, behaviour, and environmental cues.
\end{abstract}

Keywords Early ontogeny $\cdot$ Metamorphosis · Allometry · Larviculture

Krzysztof Kupren

krzysztof.kupren@uwm.edu.pl

1 Department of Tourism, Recreation and Ecology, University of Warmia and Mazury, 10-719 Olsztyn, Poland

2 Department of Lake and River Fisheries, University of Warmia and Mazury, 10-719 Olsztyn, Poland

3 Department of Aquaculture, Szent István University, Páter Károly u. 1, 2100 Gödöllő, Hungary

\section{Introduction}

For most fishes, embryonic, larval, and early juvenile development includes a few to several life-history phases that are morphologically and ecologically distinct from each other, as well as from later juveniles and adults (Kendall et al. 1984; Feeney and Swift 2008; Snyder et al. 2005). From a structural and functional perspective, morphogenesis is associated with a shift in shape coupled with abrupt or gradual changes in many morphological characters. From an ecological perspective, its most significant aspect is the occurrence of a niche shift when larvae change trophic or habitat status (Sakai 1990; Kováč et al. 2006; Nikolioudakis et al. 2010). This development is regulated by gene expression and influenced by the environment, thus resulting in different phenotypes with differential relative growth rates defined as allometry (Gilbert and Bolker 2003; Gisbert et al. 2014). Studies of the allometric growth in cyprinids at early life stages are limited and mainly focused on common carp Cyprinus carpio (e.g. Hoda and Tsukahara 1971; Osse et al. 1997; van Snik et al. 1997). In this paper, we use a multivariate approach to objectively define the transition from larval to juvenile period using morphometric as well as morphological characters and apply this method to common dace Leuciscus leuciscus - a cyprinid characterized by larger eggs and larvae than the common carp (Kennedy 1969; Kupren et al. 2011).

The common dace is a rheophilous and lithophilous species which is widely distributed throughout Europe and is a component of fish communities in the middle and lower reaches of temperate rivers (Kucharczyk 2008). In recent years, several populations of this species have declined or disappeared. The main causes of this situation are pollution of the aquatic environment, regulation of river 
flow and excessive fishing (Penczak et al. 2004). Common dace spawns relatively earlier than other cyprinids. Spawning usually takes place in March and April in fastflowing water with a shallow stony bottom. After hatching, larvae descend in prevailing currents of rivers along vegetated margins. Late larvae and early juveniles occur in shallow shoreline habitats, and when they grow leave the shores for faster-flowing areas (Mann 1974; Mills 1981; Mann 1996). Common dace are omnivorous, with a highly varied diet. Initially, larvae feed on pelagic zooplankton and, as they grow, the composition of their diet is greatly expanded. Adult common dace feeds on insects, mollusks, crustaceans, and macrophytes (Mann 1974; Hellawell 1974; Mills et al. 1985). Fragmentary descriptions of its early morphological development have been described by Kennedy (1969) and Kupren et al. (2008, 2011), but none of these studies reported age or size at larval transformation. Moreover, they do not contain information concerning allometric growth. Knowledge of fish early life history is essential for better understanding aquatic ecosystems and communities and more effectively monitoring, protecting, or managing fish populations and habitat. Such knowledge is particularly valuable in assessing environmental impacts and recovering endangered species (Snyder et al. 2005). The present study presents a comprehensive staging series for intensive reared common dace from hatching to metamorphosis, describes their morphological development based on easily recognizable external characteristics of the body, and evaluates the growth patterns of body segments. This type of data will provide insight into possible functional trends and environmental preferences of different developmental stages, establishing a reference for its normal development that might be useful for evaluating the suitability and quality of artificially reared fish for restocking purposes (Fukuhara 1986; Koumoundouros et al. 1999, 2001; Choo and Liew 2006). The acquired data might also constitute a baseline for additional studies on morphology, anatomy, ecophysiology, and behaviour of young common dace.

\section{Materials and methods}

Origin of spawners, controlled reproduction, and rearing conditions. Common dace free embryos were obtained by the controlled reproduction of wild spawners caught in Lake Mosag (northeast Poland) at the beginning of the reproductive season. The reproduction was performed according to the method described by Targońska et al. (2015) with the application of the double hormonal treatment with Ovopel. Eggs obtained from three females with an average weight of $280 \pm 45 \mathrm{~g}$ (mean \pm SD) were fertilized with semen obtained from 4 males and were subsequently incubated on Petri dishes at $12-16{ }^{\circ} \mathrm{C}$. After hatching, the free embryos were transferred to aquariums and gradually acclimated to the temperature of $25{ }^{\circ} \mathrm{C}\left(3^{\circ} \mathrm{C}\right.$ per day). Such thermal regimes have been recommended as suitable for the growth of both embryos and larvae of this species (Souchon and Tissot 2012). Individuals were reared in three $15 \mathrm{~L}$ aquariums in a closed water system as described by Krejszeff et al. (2010). The initial stocking density of individuals was 85 ind. $\mathrm{L}^{-1}$. Fish were exposed to a $12 \mathrm{~L}: 12 \mathrm{D}$ photoperiod. Larvae were fed three times a day ad libitum with freshly hatched Artemia sp. nauplii (San Francisco origin). During embryonic and larval periods, oxygen and $\mathrm{pH}$ were maintained at $>85 \%$ and 7.7 , respectively. Ammonia and nitrite (monitored with a photometer, HI 83200, Hanna Instruments, Italy) were always kept below $0.01 \mathrm{mg} \mathrm{L}^{-1}$. Survival was $93.5 \pm 4.5 \%$ to 30 days after hatching.

Measurements, data analysis, and statistics. To study the early ontogeny, seven fishes from each aquarium (total $n=21$ ) were randomly sampled daily (prior to feeding) from hatch to 30 days post-hatch (DPH). The sampled specimens were subjected to overexposure in an anesthetic solution (MS-222 at a dose of $150 \mathrm{mg} \mathrm{L}^{-1}$ ) and digital photographs of each specimen were taken using ProgRes ${ }^{\circledR}$ CapturePro 2.5 digital image analysis software (Jenoptic, Germany). After this, individuals were fixed in a $4 \%$ phosphate-buffered formaldehyde solution for further detailed examinations. Based on morphological criteria, different periods, steps and stages of early development were demarcated according to Peňaź (1974, 2001) and Peňaź et al. (1983). This system, proposed for cyprinids, was based on the instantaneous stages of ontogeny, i.e. on the characteristic moments of the development period. The morphological criteria were additionally supported by allometric indicators (inflection points) (Kendall et al. 1984; Mihelakakis et al. 2005). Thresholds during early development, such as the filling of the swim bladder and exogenous feeding commencement, were considered to be achieved when at least $50 \%$ of the specimens represented this particular stage. In each digital photograph, several body proportions associated with feeding and locomotion were measured $( \pm 0.01 \mathrm{~mm})$. These measurements included: snout length (SNL); head length (HL); trunk length (TRL); tail (post-anal) length (TAL); eye diameter (ED); head depth (HD); body depth (BD); body depth at anus level (BDA); tail depth at the caudal peduncle level (TD); and total length (TL) (Fig. 1). All measurements were taken along lines parallel or perpendicular to the horizontal axis of the body. The wet body weight (WBW) of the larvae was determined $( \pm 0.1 \mathrm{mg})$ using nylon platform according to the methodology described in Krejszeff et al. (2013). Dead or abnormal specimens (with malformations) were excluded from the analysis. 


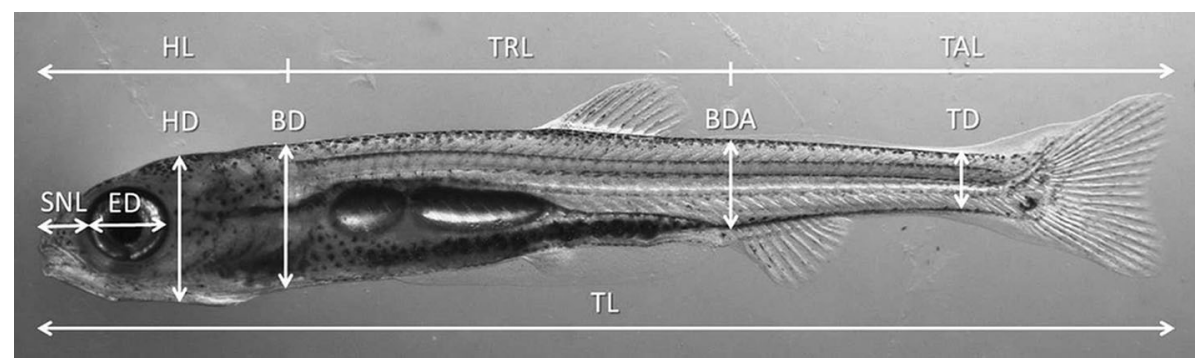

Fig. 1 Morphometric characters measured in the common dace Leuciscus leuciscus larvae. $B D$ Body depth, $B D A$ body depth at anus level, $E D$ eye diameter, $H D$ head depth, $H L$ head length, $S N L$ snout length, $T A L$ tail length, $T D$ tail depth, $T L$ total length, $T R L$ trunk length

The allometric growth of each character was expressed as a power function of TL, with the intercept and exponent obtained from linear regressions on log-transformed data. When the growth is isometric, the growth coefficient was $b=1$ for length and $b=3$ for weight when compared with TL. The inflexion points of growth curves were calculated according to van Snik et al. (1997). Growth coefficients were compared statistically using a $t$-test. The $\mathrm{x}-\mathrm{y}$ data set was sorted according to increasing $\mathrm{x}$, being TL. Regression lines were calculated for $\mathrm{x}_{\min }$ until $\mathrm{x}_{\text {intermediate, and for }}$ $\mathrm{x}_{\text {intermediate }}$ until $\mathrm{x}_{\max }, \mathrm{x}_{\text {intermediate }}$ varied iteratively from $x_{\min }+2$ to $x_{\max }-2$. Also, $t$ tests were performed to check whether the growth coefficients $\left(x_{\min } x_{\text {intermediate }}\right)$ and $\left(\mathrm{x}_{\text {intermediate }} \mathrm{x}_{\max }\right)$ differed significantly. The $\mathrm{x}_{\text {intermediate }}$ value that iteratively showed the largest $t$ was defined as the inflexion point.

\section{Results}

Growth, general morphological development, and behaviour. Between the day of hatching and $30 \mathrm{DPH}$, the mean growth rate of common dace individuals was 0.50 $\mathrm{mm} \mathrm{day}^{-1}$ (mean TL was 7.47 and $22.44 \mathrm{~mm}$ in $0 \mathrm{DPH}$ and $30 \mathrm{DPH}$, respectively) (Fig. 2). During this time, three periods and eight different steps of development were observed. The monitoring included the final part of the embryonic period (step: ES9), the whole larval period (LS1-LS6), and the initial part of the juvenile period (JS1). During post-hatch development, the fish underwent a change from endogenous to exogenous feeding and the various organs gradually differentiated and became identifiable. Hatching occurred at the stage described as ES9 $(7.47 \pm 0.29 \mathrm{~mm}$ TL). The yolk sac was completely consumed at $3 \mathrm{DPH}\left(\mathrm{LS} 2 / \mathrm{LS}_{\mathrm{a}}\right.$ ), when TL was $8.61 \pm 0.39$ $\mathrm{mm}$. The notochord flexion occurred between $4 \mathrm{DPH}$ $\left(\mathrm{LS}_{\mathrm{b}}\right)$ and $10 \mathrm{DPH}\left(\mathrm{LS}_{\mathrm{a}}\right)$ at $9.05 \pm 0.41$ and 11. $27 \pm 1.20 \mathrm{~mm}$, respectively. The finfold was completely absorbed at 28 DPH (JS1; $20.04 \pm 1.84 \mathrm{~mm} \quad$ TL) (Table 1). At this stage, the body shape of larvae and the

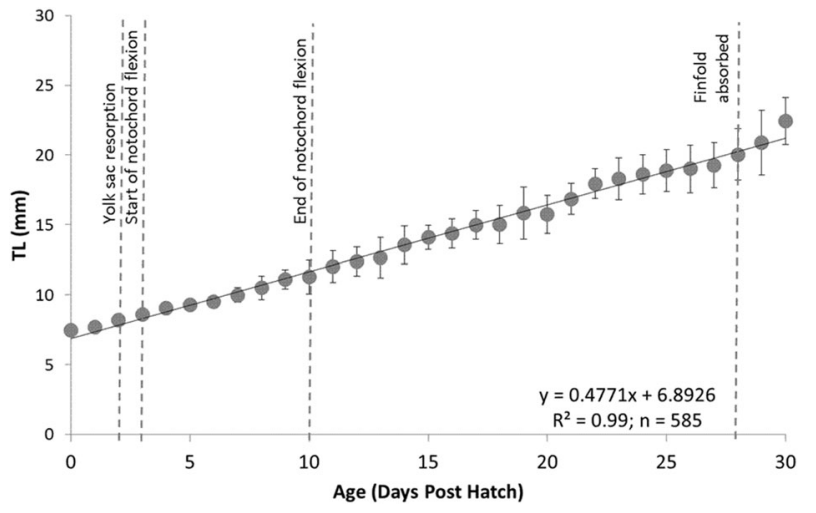

Fig. 2 Changes in total length (TL) of Leuciscus leuciscus during the early stages of development (from hatching to $30 \mathrm{DPH}$ ) at $25^{\circ} \mathrm{C}$. Bars indicate standard deviation

pigmentation pattern on the lateral side of the body were similar to those of the adults and all fins were well developed (Fig. 3).

Immediately after hatching, the free embryos remained passively on the bottom of the tank with occasional jerky movements. One day later (1 DPH), the posterior chamber of the swim bladder was filled and most of them swam and maintained their position in the water column. From that time until the end of the experiment, the larvae were visual feeders, actively searching for food in all parts of the tank. Table 1 gives details of the stages of free embryo and larva as illustrated in Fig. 3.

Allometric growth. The WBW and TL relationship is given in Fig. 4. The growth coefficient $b$ was 3.46. This value was higher than the isometric value, thus reflecting a positive allometric growth for this species. Allometric growth equations between nine measured body segments and TL (6.66$25.41 \mathrm{~mm}$ ) are presented in Fig. 5. During this period, the body proportions and growth rates changed considerably. For specific parts of the body, inflexion points ranged from $15.35 \mathrm{~mm}$ TL for ED to $21.78 \mathrm{~mm}$ TL for TAL (Fig. 5). Head growth could be divided into two different phases (Fig. 5ac). HD, HL, and SNL showed positive allometric initial growth ( $b=1.26,1.31$ and 1.80 , respectively) until their respective inflexion points at $16.68,18.11$, and $18.95 \mathrm{~mm}$ 
Table 1 The major morphological and behavioural events during early development of common dace Leuciscus leuciscus

\begin{tabular}{|c|c|c|c|}
\hline DS & DPH & Total length (mm) & Characteristic features \\
\hline \multicolumn{4}{|l|}{ ES9 } \\
\hline \multirow[t]{3}{*}{ stage a } & 0 & $6.99-7.84(7.47)$ & $\begin{array}{l}\text { Reflective guanine in eye. Head slightly bent down, body straight. Yolk sac pear } \\
\text { shaped. Blood circulation in branchial arches. Mouth closed. No fins } \\
\text { differentiated. Primordial finfold well developed in sagittal plane Pigmentation } \\
\text { present on body, especially intensive along the dorsal part of the body (Fig. 3a) }\end{array}$ \\
\hline & & & Behaviour \\
\hline & & & $\begin{array}{l}\text { Hatching. Embryos do not show photophobia and lay on the bottom. Embryos } \\
\text { cannot swim actively. Short periods of horizontal darting movements are } \\
\text { observed }\end{array}$ \\
\hline stage $b$ & 1 & $7.13-8.12(7.69)$ & $\begin{array}{l}\text { Whole body straight. Yolk sac at an advanced stage of resorption-conical } \\
\text { shape. Lower jaw mobile reaches the front edge of eye. Cuvier ducts } \\
\text { disappeared }\end{array}$ \\
\hline \multirow[t]{3}{*}{ stage c } & 1 & $7.13-8.12(7.69)$ & $\begin{array}{l}\text { Posterior chamber of swim bladder slightly inflated. Filaments form on branchial } \\
\text { arches. Number and size of melanophores on the surface of body are } \\
\text { increasing. Gill cover is developing (Fig. 3b) }\end{array}$ \\
\hline & & & Behaviour \\
\hline & & & Embryos swim up to the surface to fill their swim bladder \\
\hline \multirow[t]{3}{*}{ LS1 } & 2 & $7.85-8.54(8.17)$ & $\begin{array}{l}\text { Lower jaw reaches terminal position. Beginning of exogenous (mixed) feeding. } \\
\text { Remains of yolk sac present (Fig. 3c) }\end{array}$ \\
\hline & & & Behaviour \\
\hline & & & Larvae swim actively in the water column \\
\hline LS2 & 3 & $7.89-9.47(8.61)$ & Yolk sac completely resorbed (Fig. 3d) \\
\hline \multicolumn{4}{|l|}{ LS3 } \\
\hline \multirow[t]{3}{*}{ stage a } & 3 & $7.89-9.47(8.61)$ & $\begin{array}{l}\text { Mesenchymal lepidotrichia (lepidotrichia begin differentiation) in the caudal and } \\
\text { pectoral fin (Fig. 3d) }\end{array}$ \\
\hline & & & Behaviour \\
\hline & & & Larvae swim actively in the whole water column \\
\hline stage $b$ & 4 & $8.19-9.48(9.05)$ & Start of notochord flexion, heterocercal shape of caudal fin (Fig. 3e) \\
\hline \multicolumn{4}{|l|}{ LS4 } \\
\hline stage a & 6 & $8.88-10.07(9.51)$ & Ossified rays in the caudal fin. Mesenchymal lepidotrichia in dorsal fin \\
\hline stage $b$ & 9 & $9.76-12.66(11.10)$ & $\begin{array}{l}\text { Anterior chamber of swim bladder filled with gas. Mesenchymal lepidotrichia in } \\
\text { anal fin. Caudal fin bifurcate (definite homocercal shape) (Fig. 3f) }\end{array}$ \\
\hline \multicolumn{4}{|l|}{ LS5 } \\
\hline stage a & 10 & $9.50-13.58(11.27)$ & $\begin{array}{l}\text { Notochord flexion completed. Pelvic fin buds present. Dorsal fin almost fully } \\
\text { detached from finfold (Fig. 3g) }\end{array}$ \\
\hline stage $b$ & 17 & $13.71-17.02(14.99)$ & Pelvic fin reaches edge of finfold (Fig. 3h) \\
\hline LS6 & 21 & $15.36-19.79(16.86)$ & $\begin{array}{l}\text { Pelvic fins extend beyond edge of finfold. Finfold present only between pelvic } \\
\text { and anal fin (Fig. 3i) }\end{array}$ \\
\hline JS1 & 28 & $16.71-22.95(20.04)$ & Finfold completely reduced. Scales present (Fig. 3j) \\
\hline
\end{tabular}

$D S$ developmental step; $D P H$ days post-hatch; $E S$ embryonic steps; $L S$ larval steps; $J S$ juvenile step

Means in parentheses

TL. After these sizes, relative SNL and HD growth became weakly allometric $(b=1.09$ and $b=1.23, P<0.001$, respectively), while HL growth was isometric $(b=1.02$, $P<0.001$ ) (Fig. 5a-c). A similar growth model was characteristic for ED (slope $=1.24$ to 0.99 ) with an inflexion point at a TL of $15.35(P<0.001)$ (Fig. 5d). Allometric growth of TD, BDA, and TAL was also biphasic with an initially positive allometric growth from hatching to their inflexion point (Fig. 5e-g). TD and BDA were strongly positively allometric ( $b=1.76$ and 1.52 , respectively) until their respective inflexion points at 17.94 and $19.21 \mathrm{~mm}$ TL and then decreased, becoming slightly allometric $(b=1.19$ and 1.35, $P<0.001$ ). The tail length showed slight positive allometric growth $(b=1.24)$ from hatching to $21.78 \mathrm{~mm}$ TL, followed by a near isometric growth $(b=0.94$, $P<0.001)$ until the end of the study. BD increased positively allometrically $(b=1.20)$ throughout the study (Fig. 5h). The growth of TRL also showed no inflexions (simple linear regression), with a constant growth rate of 0.66 (negatively allometrically) (Fig. 5i). 
Fig. 3 Morphological development of the common dace Leuciscus leuciscus. a Stage $\mathrm{ES9}_{\mathrm{a}}, 0 \mathrm{DPH}$; b stage $\mathrm{ES} 9_{\mathrm{b}} / \mathrm{ES} 9_{\mathrm{c}}, 1 \mathrm{DPH} ; \mathbf{c}$ stage LS1, 2 DPH; d stage LS2/LS3 3 $\mathrm{DPH}$; e stage $\mathrm{LS}_{\mathrm{b}}$, $4 \mathrm{DPH}$; f stage $\mathrm{LS}_{\mathrm{b}}, 9 \mathrm{DPH} ; \mathbf{g}$ stage $\mathrm{LS}_{\mathrm{a}}, 10 \mathrm{DPH} ; \mathbf{h}$ stage $\mathrm{LS} 5_{\mathrm{b}}, 17$ DPH; i stage LS6, $21 \mathrm{DPH}$; j stage LSJ1, 28 DPH). Scale bars $2 \mathrm{~mm}$
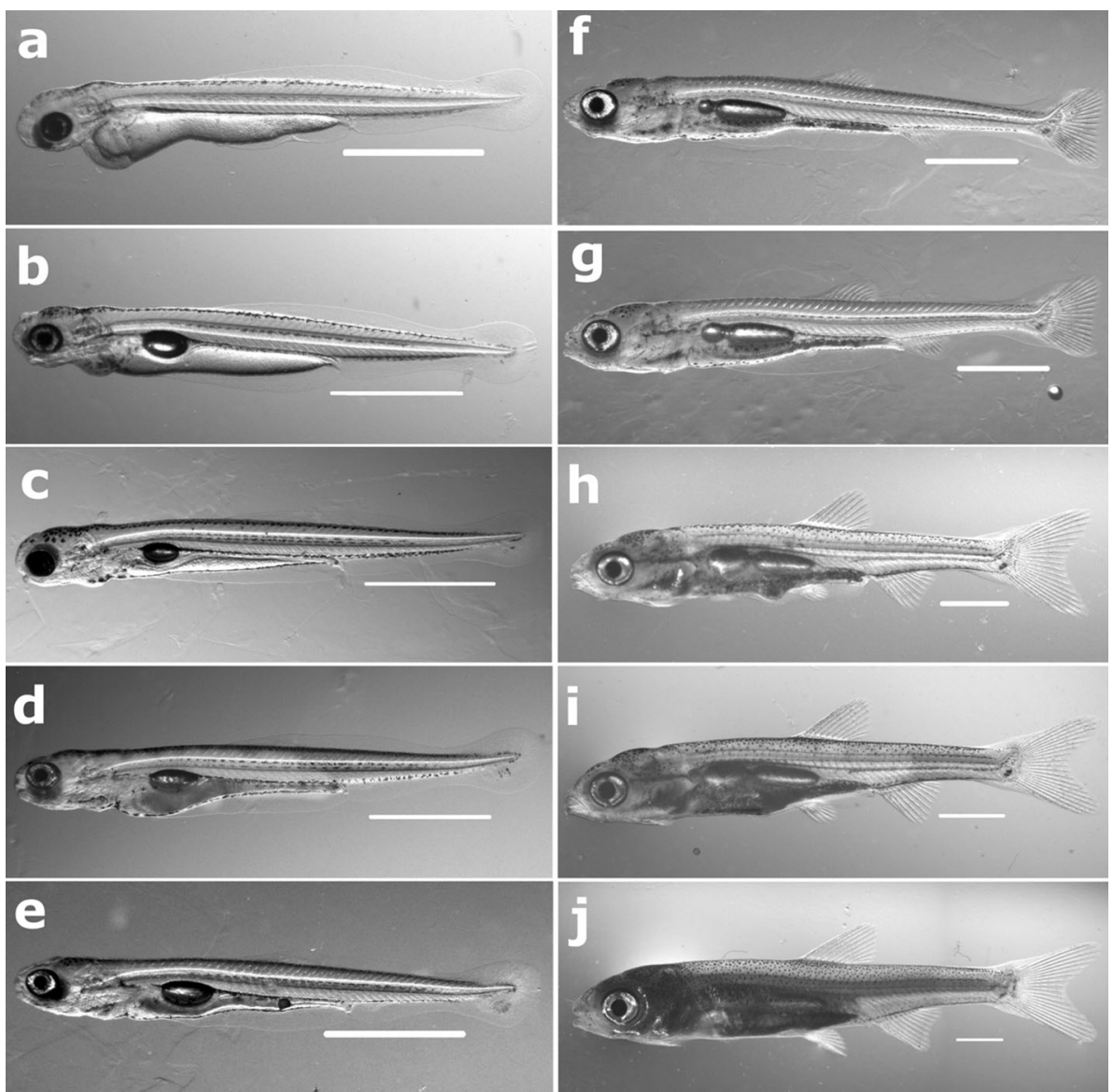

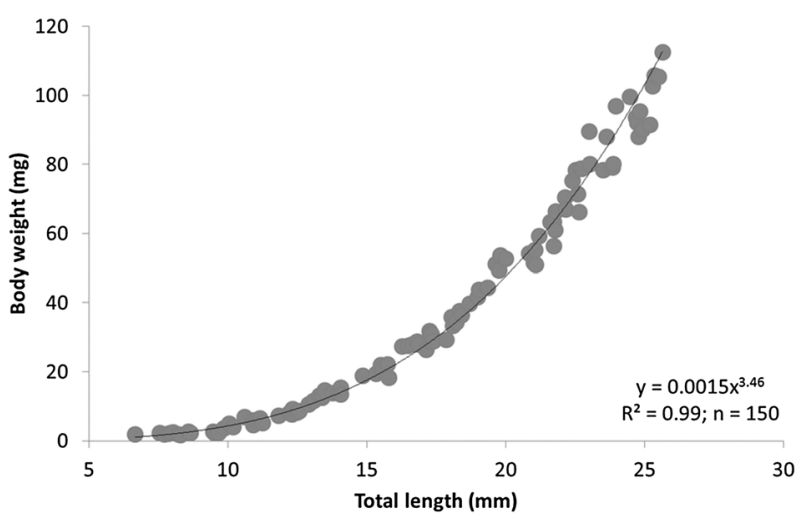

Fig. 4 Allometric growth equations and relationship between body weight and total length in Leuciscus leuciscus during the early stages of development (from hatching up to day 30)

\section{Discussion}

The morphological changes and the size distribution during each developmental stage reported in this study are in accordance with those previously described by Kennedy (1969) and Kupren et al. (2008) in reared larvae of the same species. By the more comprehensive observation regarding changes in the body shape and functional trends, we obtained results contributing to more detailed knowledge of the early development of the common dace. Moreover, successions of morphological thresholds presented in this paper closely follow the pattern reported for carp Cyprinus carpio (see Peňaź et al. 1983) and other cyprinids; therefore the developmental stage system based on the most characteristic moments in fish development proposed for cyprinids by Peňaź (2001) is fully applicable to common dace. According to Peňaź (2001), the sequence of appearance of most development events in cyprinids are mostly stable, with the exceptions of the rate and duration of yolk sac absorption, which can vary greatly depending upon the size of egg and amount of yolk. Consecutive variation can be seen in some other phenomena also closely associated with the volume of yolk sac (e.g. stages of hatching, first free swimming, and first intake of exogenous food). At the moment of hatching, common dace is more advanced in their development than the individuals of majority of teleost fish species (Kennedy 1969; Kupren et al. 2008, 2011). The newly hatched common dace have almost a straight body with the head clearly separated from the yolk sac at an advanced stage of absorption. Within a few hours following emergence, free embryos start to swim 

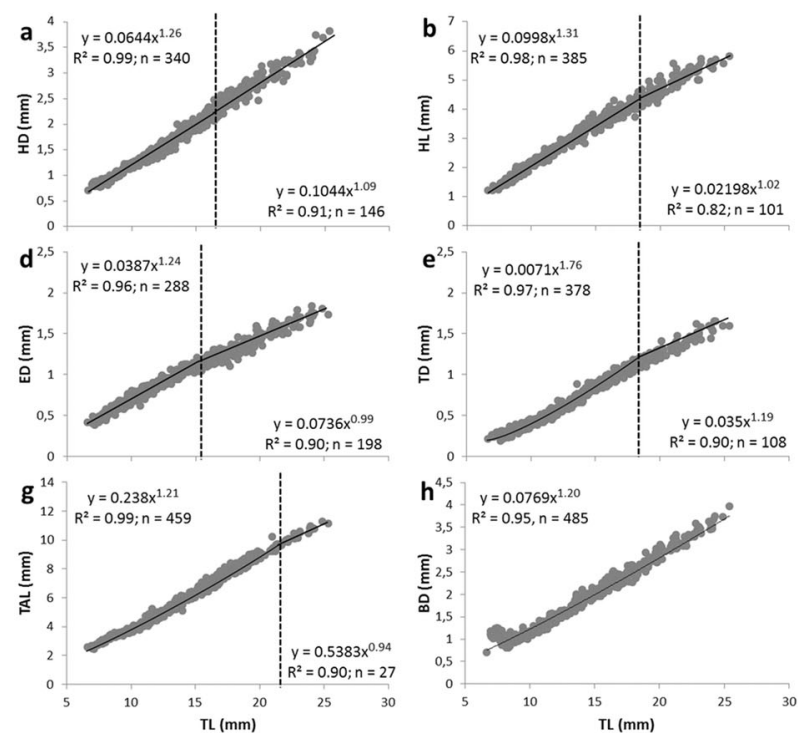

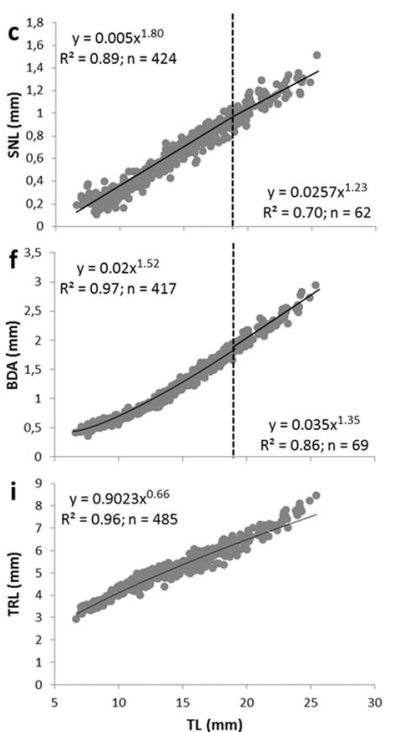

(inflexion point at $15.35 \mathrm{~mm}$ TL, day 18); e TD - tail depth at the caudal peduncle level (inflexion point at $17.94 \mathrm{~mm} \mathrm{TL}$, day 22); f BDA-body depth at anus level (inflexion point at $19.21 \mathrm{~mm}$ TL, day 27); g TAL-tail (post-anal) length (inflexion point at $21.78 \mathrm{~mm}$ TL, day 30); h BD—body depth; i TRL—trunk length. Dashed line indicates inflection point of growth

smallest yolk sacs hatch at temperatures within the optimum range. At other temperatures, the individuals that left the egg membranes usually show less advanced ontogenic development (Kokurewicz 1969, 1970; Kupren et al. 2011). The reason for faster hatching of embryos at higher temperatures is their increased mobility in warmer water and earlier excretion of the hatching enzyme (Blaxter 1969, 1992; Kamler 1992; Kamler et al. 1998; Korwin-Kossakowski 2012).

During early ontogeny, embryonic adaptations and functions of common dace were replaced by definitive features, such as branchial respiration, exogenous feeding, and active swimming. Such modifications involved extreme modifications in the relationship of the developing fish with the environment and were reflected in morphological and morphometric changes. In most fish species, e.g. Siberian sturgeon Acipenser baerii (see Gisbert 1999), California halibut Paralichthys californicus (see Gisbert et al. 2002), African catfish Clarias gariepinus, carp (see van Snik et al. 1997), and burbot Lota lota (see Kupren et al. 2014a), the process of early remodeling was linked to the positive allometric growth of many morphological characters. During a short period, growth slows down (Hoda and Tsukahara 1971; Fuiman 1983). In older larvae and juveniles, all growth coefficients approach 1 (near-isometric growth) (Gisbert 1999; Osse and van den Boogart 2004). This change to isometry, observed particularly in anterior and posterior body regions, is considered to be a natural transition in growth priorities since the primary functions, such as feeding 
and swimming, were fulfilled during early development (Ushaped pattern of development) (Fuiman 1983). Similar growth priorities with a positive allometric growth of anterior and posterior regions during early development are also observed in common dace. The fast initial growth in the head region (allometric growth of HL, HD, ED) is probably linked to the development of nervous (midbrain and hindbrain), sensory (vision and olfaction), respiratory (gill arches and filaments), and feeding systems. Increasing head size is associated with a more developed nervous system, allowing better oxygen uptake and the application of food particles of increasing size (Fuiman 1983; van Snik et al. 1997, Koumoundouros et al. 1999; Gisbert et al. 2002; Kupren et al. 2014b). In the posterior part of the body, rapid tail growth of dace individuals (allometric growth of TAL, BDA, and TD) was concomitant with the development of musculature, unpaired fins, caudal peduncle, and fin rays. Such changes contribute to improved swimming ability (Fuiman 1983; Peña and Dumas 2009; Khemis et al. 2013; Kupren et al. 2014a, b).

The reported positive allometric growth of the anterior and posterior parts of the larval body, prior to the development of the trunk region, could be also interpreted as an adaptation to increase swimming efficiency (van Snik et al. 1997; Koumoundouros et al. 1999). Consequently, the rapid growth of the head and tail closely parallels the desirability of reducing drag forces on the body and attaining higher locomotion speed (Osse and van den Boogart 2004). Another possible mechanism for reducing drag forces during early life stages is the achievement of a fusiform, streamlined body. With the reduction of the pre-anal finfold, the body obtains a more fusiform shape by the growth of the gut and the accompanied coiling of the intestine (Hoda and Tsukahara 1971). In the common dace, the growth of the depth of the central segment of the body (with synchronized elongation of the anterior and posterior segment) is reflected in the positive allometric growth of $\mathrm{BD}$ and $\mathrm{BDA}$ throughout the free embryo and larval periods.

No change in the overall growth rates (Fig. 4) and the asynchronous inflexion points in parameters which show biphasic growth observed in this study (15.35-21.78 mm TL, Fig. 5) indicate a gradual change in the body shape. In many fish species, a reduction in the growth coefficients of various organs and tissues occurs at very similar body lengths and is correlated to typical morphogenetic events. These abrupt changes in body proportions are usually concomitant with notochord flexion when the first rays primordia appear on the ventral side of the caudal tip. In carp (van Snik et al. 1997; Osse et al. 1997), for example, inflexion points found around $7 \mathrm{~mm}$ TL correspond with dramatic shift in increased swimming capability. The gradual changes in body proportions of common dace are probably related to the lack of sharp changes in behaviour and habitat (observed both under laboratory and natural conditions) and may also be considered to be a gradual adaptation to life in flowing water.

In this paper, we could estimate the size range of early life period of common dace (embryo, larva; sensu Peňaź 2001) on the basis of the relative growth and morphogenesis. The growth analysis conducted in this paper shows that the replacement of temporary structures (e.g. finfold absorption) and the appearance of definitive structures at about $21 \mathrm{~mm}$ TL correspond to stabilization in the relative growth. This is probably a consequence of the common dace finishing the remodeling process (metamorphosis) and achieving their final body shape, allowing juveniles to colonize faster water habitats. Changes in body proportions usually take place during the larval or early juvenile period, although some changes in body proportions (often related to changes in function and habitat) in many species (e.g. crucian carp Carassius carassius) may also take place later during the juvenile and adult periods as a response to the presence of predators and enhanced food availability (Urho 2002).

Open Access This article is distributed under the terms of the Creative Commons Attribution 4.0 International License (http://crea tivecommons.org/licenses/by/4.0/), which permits unrestricted use, distribution, and reproduction in any medium, provided you give appropriate credit to the original author(s) and the source, provide a link to the Creative Commons license, and indicate if changes were made.

\section{References}

Balon EK (1990) Epigenesis of an epigeneticist: the development of some alternative concepts on the early ontogeny and evolution of fishes. Guelph Ichthyol Rev 1:1-48

Blaxter JHS (1969) Development: eggs and larvae. In: Hoar WS, Randall DJ (eds) Fish physiology. Vol 3. Reproduction and growth. Academic Press, New York, pp 177-252

Blaxter JHS (1992) The effect of temperature on larval fishes. Neth J Zool 42:336-357

Choo CK, Liew HC (2006) Morphological development and allometric growth patterns in the juvenile seahorse Hippocampus kuda Bleeker. J Fish Biol 69:426-445

Feeney RF, Swift CC (2008) Description and ecology of larvae and juveniles of three native cypriniforms of coastal southern California. Ichthyol Res 55:65-77

Fuiman LA (1983) Growth gradients in fish larvae. J Fish Biol 23:117-123

Fukuhara O (1986) Morphological and functional development of Japanese flounder in early life stages. Nippon Suisan Gakkaishi 52:81-91

Gilbert SF Bolker JA (2003) Ecological developmental biology: preface to the symposium. Evol Dev 5:3-8

Gisbert E (1999) Early development and allometric growth patterns in Siberian sturgeon and their ecological significance. J Fish Biol $54: 852-862$

Gisbert E, Merino GE, Mugeut JB, Bush D, Piedrahita RH, Conklin DE (2002) Morphological development and allometric growth patterns in hatchery-reared California halibut larvae. J Fish Biol 61:1217-1229 
Gisbert E, Asgari R, Rafiee Gh, Agh N, Eagderi S, Eshaghzadeh H, Alcaraz C (2014) Early development and allometric growth patterns of beluga Huso huso (Linnaeus, 1758). J Appl Ichtyol 30:1264-1272

Hellawell JM (1974) The ecology of populations of dace, Leuciscus leuciscus (L.), from two tributaries of the river Wye, Herefordshire, England. Freshw Biol 4:577-604

Hoda SMS, Tsukahara H (1971) Studies on the development and relative growth in the carp, Cyprinus carpio L. J Fac Agr Kyushu U 16:387-509

Kamler E (1992) Early life history of fish: an energetics approach. Chapman and Hall, London

Kamler E, Keckeis H, Bauer-Nemeschkal E (1998) Temperatureinduced changes of survival, development and yolk partitioning in Chondrostoma nasus. J Fish Biol 53:658-682

Kendall AW, Ahlstrom EH, Moser HG (1984) Early life history stages of fishes and their characters. In: Moser HG, Richards WJ, Cohen DM, Fahay MP, Kendall AW, Richardson SL (eds) Ontogeny and systematics of fishes. American Society of Ichthyologists and Herpetologists, Special Publication No. 1. Allen Press Inc, Lawrence, pp 11-24

Kennedy M (1969) Spawning and early development of the dace (Leuciscus leuciscus L.). J Fish Biol 1:249-259

Khemis BI, Gisbert E, Alcaraz C, Zouiten D, Besbes R, Zouiten A, Masmoudi AS, Cahu C (2013) Allometric growth patterns and development in larvae and juveniles of thick-lipped grey mullet Chelon labrosus reared in mesocosm conditions. Aquac Res 44:1872-1888

Kokurewicz B (1969) The influence of temperature on the embryonic development of the perches (Perca fluviatilis L.) and (Lucioperca lucioperca). Zool Pol 19:47-67

Kokurewicz B (1970) The effect of temperature on embryonic development of Tinca tinca (L.) and Rutilus rutilus (L.). Zool Pol 20:317-337

Korwin-Kossakowski M (2008) The influence of temperature during the embryonic period on larval growth and development in carp, Cyprinus carpio L., and grass carp, Ctenopharyngodon idella (Val.): theoretical and practical aspects. Arch Pol Fish 16:231-314

Korwin-Kossakowski M (2012) Fish hatching strategies: a review. Rev Fish Biol Fish 22:225-240

Korzelecka-Orkisz A, Bonisławska M, Pawlos D, Szulc J, Winnicki A, Formicki K (2009) Morphophysiological aspects of embryonic development of tench (Tinca tinca L.). EJPAU 12 (4), \#21. http://www.ejpau.media.pl/volume12/issue4/art-21.html. Accessed 26 January 2015

Korzelecka-Orkisz A, Bonisławska M, Tański A, Smaruj I, Szulc J, Formicki K (2013) Embryonic development of Aspius aspius L (Actinopterygii: Cypriniformes: Cyprinidae). EJPAU 16(3), \#09. http://www.ejpau.media.pl/volume16/issue3/art-09.html. Accessed 26 January 2015

Koumoundouros G, Divanach P, Kentouri M (1999) Ontogeny and allometric plasticity of Dentex dentex (Osteichthyes: Sparidae) in rearing conditions. Mar Biol 135:561-572

Koumoundouros G, Divanach P, Anezaki L, Kentouri M (2001) Temperature-induced ontogenetic plasticity in sea bass (Dicentrarchus labrax). Mar Biol 139:817-830

Kováč V, Katina S, Copp GH, Siryova S (2006) Ontogenetic variability in external morphology and microhabitat use of spirlin Alburnoides bipunctatus from the River Rudava (Danube catchment). J Fish Biol 68:1257-1270

Krejszeff S, Żarski D, Kucharczyk D, Kupren K, Targońska K, Mamcarz A (2010) An experimental device for egg incubation and fish larvae rearing under laboratory conditions. Pol J Nat Sci 25:190-199
Krejszeff S, Żarski D, Palińska-Żarska K, Trąbska I, Kupren K, Targońska K, Bowszys M, Kucharczyk D (2013) Procedure for harmless estimation of fish larvae weight. Ital $\mathrm{J}$ Anim Sci $12: 270-274$

Kucharczyk D (2008) Jelec Leuciscus leuciscus (Linnaeus, 1758). In: Mamcarz A (ed) Larwikultura reofilnych ryb karpiowatych, Mercurius Kaczmarek Andrzej, Olsztyn, pp 395-434

Kupren K, Mamcarz A, Kucharczyk D, Prusińska M (2008) Changes in morphometric parameters in selected early stages of three fish species from the genus Leuciscus (Teleostei, Cyprinidae). Arch Pol Fish 16:421-436

Kupren K, Mamcarz A, Kucharczyk D (2011) Effect of variable and constant thermal conditions on embryonic and early larval development of fish from the genus Leuciscus (Cyprinidae, Teleostei). Czech J Anim Sci 56:70-80

Kupren K, Trąbska I, Żarski D, Krejszeff S, Palinska-Żarska K, Kucharczyk D (2014a) Early development and allometric growth patterns in burbot Lota lota L. Aquac Int 22:29-39

Kupren K, Prusińska M, Zarski D, Krejszeff S, Kucharczyk D (2014b) Early development and allometric growth in Nannacara anomala Regan, 1905 (Perciformes: Cichlidae) under laboratory conditions. Neotrop Ichthyol 12:659-665

Kupren K, Żarski D, Kucharczyk D (2015a) Early development and allometric growth patterns in ide Leuciscus idus (Linnaeus 1758). J Appl Ichthyol 31:509-517

Kupren K, Nowosad J, Żarski D, Targońska K, Hakuć-Błażowska A, Kucharczyk D (2015b) Early development and allometric growth in laboratory-reared European Chub Leuciscus cephalus (Linnaeus, 1758). Turk J Fish Aquat Sci 15:391-398

Mann RHK (1974) Observations on the age, growth, reproduction and food of the dace, Leuciscus leuciscus (L.), in two rivers in southern England. J Fish Biol 6:237-253

Mann RHK (1996) Environmental requirements of European nonsalmonid fish in rivers. Hydrobiologia 323:223-235

Mihelakakis A, Tsoklas C, Yoshimatsu T (2005) Early Development of Laboratory-reared Common Dentex, Dentex dentex (L.). Aquacult Sci 53:367-376

Mills CA (1981) The attachment of dace, Leuciscus leuciscus L., eggs to the spawning substratum and the influence of changes in water current on their survival. J Fish Biol 19:129-134

Mills CA, Beaumont WRC, Clarke RT (1985) Sources of variation in the feeding of larval dace Leuciscus leuciscus in an English river. Trnas Am Fish Soc 114:519-524

Nikolioudakis N, Koumoundouros G, Kiparissis S, Somarakis S (2010) Defining length-at- metamorphosis in fishes: a multicharacter approach. Mar Biol 157:991-1001

Osse JWM, van den Boogart JGM (2004) Allometric growth in fish larvae: timing and function. In: Govoni J (ed) The development of form and function in fishes and the question of larval adaptation., American Fisheries Society Syposium, Bethesda, pp 167-194

Osse JWM, van den Boogart JGM, van Snik GMJ, van der Sluys L (1997) Priorities during early growth of fish larvae. Aquaculture 155:249-258

Peña R, Dumas S (2009) Development and allometric growth patterns during early larval stages of the spotted sand bass Paralabrax maculatofasciatus (Percoidei: Serranidae). Sci Mar, 73S1:183-189

Peňaź M (1974) Influence of water temperature on incubation and hatching in Chondrostoma nasus (Linnaeus, 1758). Zool Listy 23:53-59

Peňaź M (2001) A general framework of fish ontogeny: a review of the ongoing debate. Folia Zool 50:241-256

Peňaź M, Wohlgemuth E, Hamáčková J, Kouřil J (1981) Early ontogeny of the tench, Tinca tinca L. Embryonic period. Folia Zool 30:165-176 
Peňaź M, Prokeš M, Kouřil J, Hamačkowa J (1983) Early development of the carp, Cyprinus carpio. Acta Sci Natur Brno 17:1-39

Penczak T, Galicka W, Głowacki Ł, Koszaliński H, Kruk A, Zięba G, Kostrzewa J, Marszał L (2004) Fish assemblage changes relative to environmental factors and time in the Warta River, Poland, and its oxbow lakes. J Fish Biol 64:483-501

Sakai H (1990) Larval developmental intervals in Tribolodon hakonensis (Cyprinidae). Jpn J Ichthyol 37:17-28

Snyder DE, Bestgen KR, Seal SC (2005) Native cypriniform fish larvae of the Gila River Basin, morphological descriptions, comparisons, and computer-interactive keys. Final report to the Bureau of Reclamation, U.S. Department of the Interior, Phoenix, AZ

Souchon Y, Tissot L (2012) Synthesis of thermal tolerances of the common freshwater fish species in large Western Europe rivers. Knowl. Managt. Aquatic Ecosyst (405), 03
Targońska K, Kupren K, Kujawa R, Mamcarz A, Kaczkowski Z, Glogowski J, Kowalski RK, Żarski D, Wyszomirska E, Kucharczyk D (2015) Artificial reproduction of different dace, Leuciscus leuciscus (L.) populations as a method for biodiversity preservation. Turkish J Fish Aquat Sci 15:477-485

Teletchea F, Fostier A, Kamler E, Gardeur JN, Le Bail PY, Jalabert B, Fontaine, P (2009) Comparative analysis of reproductive traits in 65 freshwater fish species: application to the domestication of new fish species. Rev Fish Biol Fish 19:403-430

Urho L (2002) Characters of larvae-what are they? Folia Zool $51: 161-186$

van Snik GMJ, van den Boogaart JGM, Osse WM (1997) Larval growth patterns in Cyprinus carpio and Clarias gariepinus with attention to the finfold. J Fish Biol 50:1339-1352 